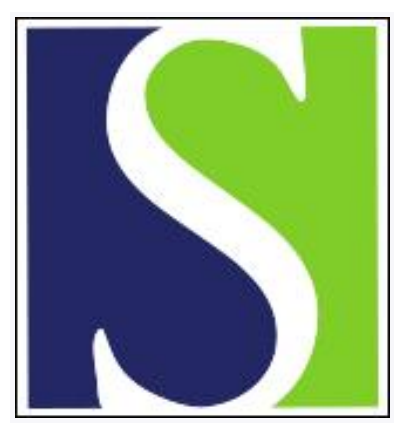

Scand J Work Environ Health 1999;25(6):550-557

https://doi.org/10.5271/sjweh.479

Issue date: Dec 1999

Challenges for research and prevention in relation to work and cardiovascular diseases

by Kristensen TS

The following articles refer to this text: 2001;27(3):161-213;

2002;28(2):94-108

Key terms: epidemiologic method; IHD; ischemic heart disease; pshychosocial factor; review; stress

This article in PubMed: www.ncbi.nlm.nih.gov/pubmed/10884152

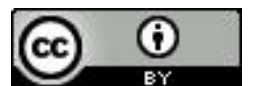




\title{
Challenges for research and prevention in relation to work and cardiovascular diseases
}

\author{
by Tage S Kristensen, DMSC ${ }^{7}$
}

\begin{abstract}
Kristensen TS. Challenges for research and prevention in relation to work and cardiovascular diseases. Scand $J$ Work Environ Health 1999;25(6, special issue):550—557.

The purpose of this paper is to discuss future challenges for research and prevention in the field of work environment and cardiovascular diseases (CVD). First, research on CVD and work during the last half of the 20th century is discussed. Second, the theories dominating the last 20 years are presented. Third, cardiovascular and occupational epidemiology are compared, and it is stressed that occupational epidemiology should avoid the individualistic bias of mainstream cardiovascular epidemiology. Finally, future challenges are discussed, and improvements are recommended concerning the use of intermediate end points, intervention research, theories about chemical and physical risk factors, the use of a unifying model for society, stress, and health, and the application of integrated prevention. It is concluded that research on CVD and work can play an important part in the development of integrated prevention strategies for the next century.
\end{abstract}

Key terms epidemiologic methods, ischemic heart disease, psychosocial factors, review, stress.

One of the serious epidemics of the 20th century has been that of cardiovascular diseases (CVD). Starting as diseases of the upper classes in affluent countries, CVD gradually, during the last 3 to 5 decades, also turned into being a problem of the lower class of these countries (1). During the same period the mortality and incidence of CVD decreased in most of these countries. However, if we take a more global look, the epidemic of CVD seems to be far from ending. CVD mortality has been increasing in the former Communist countries, and in a number of other countries as well, and predictions for the $21 \mathrm{st}$ century indicate that CVD will constitute the major burden of disease in the world in the foreseeable future (2).

Since the end of World War II, epidemiologic research has established several individual risk factors for CVD, such as high blood pressure, high serum cholesterol, tobacco smoking, obesity, physical inactivity, heredity, and dietary factors. The role of stress and personality factors has been studied and debated intensely (3), but the significance of these factors is not universally accepted. Broader constructs, such as social class, social network and support, social integration, life events, and unemployment, have also been linked to CVD, and most studies have found clear associations $(1,3-7)$. These associations are still not fully understood, and the search for explanatory mechanisms continues.
With regard to occupational risk factors, the research effort has been substantial, as demonstrated in several reviews on CVD and work published during the last 20 years (8-18). This research has, however, been less well coordinated and disseminated, which is well illustrated by the conclusion of a recent review by Steenland (8), from the National Institute for Occupational Safety and Health in the United States: "Little is known about occupational risks for coronary heart disease" [p 495]. I shall not go into the problems of causal inference in this article, but only say that many of the occupational factors linked to CVD in the literature are still not well established as causal risk factors. The majority of the nonchemical and chemical factors discussed in the literature are included in the following list:
Nonchemical factors
- job strain
- effort-reward imbalance
- other job stressors
- shift work
- sedentary work
- heat
- cold
- electromagnetic fields
Chemical factors
- carbon disulfide
- nitroglycol and nitroglycerin

1 National Institute of Occupational Health, Copenhagen, Denmark.

Reprint requests to: Mr Tage S Kristensen, National Institute of Occupational Health, Lerso Parkalle 105, DK-2100 Copenhagen $\emptyset$, Denmark. [E-mail: tsk@ami.dk] 
- carbon monoxide

- passive smoking

- lead

- dioxin

- cobalt

- solvents

- organophosphates

- arsenic

- antimony

In an article from 1991 (19), my colleagues and I estimated the overall causal role of occupational CVD risk factors in Denmark and concluded that the etiologic fraction was $16 \%$ for men and $22 \%$ for women. (When we included sedentary work, the fraction was $51 \%$ for men and $55 \%$ for women.) This finding demonstrates that the potential preventive impact is considerable.

\section{Research on cardiovascular diseases and work since 1950}

Before discussing the future of this field, I suggest that we take a look at the research performed during the last 50 years in order to learn from successes and failures. In table 1 I have listed 18 "highlights" published between 1950 and 1999 (20-46). I have chosen these highlights for their high degree of conclusiveness. Many of these studies are of the intervention type or "natural experiments" or can be perceived and interpreted as being experiments. A good example is the study of tax accountants by Friedman et al (23), in which the deadline for tax returns was the "experimental stimulus". Another example is the Kornitzer \& Kittel study (28-29), in which 2 cohorts were followed for 10 years (employees in a private bank with high job stress and employees in a semipublic savings bank with lower job stress). One of the studies, the studies on electromagnetic fields and hospitalization by Perry \& Pearl (33), had all the characteristics of a randomized controlled trial: "randomization" of exposure and blinding of both participants and hospital physicians.

The studies in table 1 cover many different exposures: lack of physical activity ( $20-22)$, temporary job stress $(23,27,34,35)$, carbon disulfide $(24,25)$, aircraft noise (26), chronic stress $(28,29,32)$, nitroglycol and nitroglycerin (30), shift work (31), electromagnetic fields (33), unemployment (34), threats of unemployment (35), lifestyle factors $(36,37)$, dioxin (38), passive smoking (39), worksite noise (40), and socioeconomic status (41-43). They do, however, have 2 important features in common. They are all extremely well focused on one specific exposure, and they all include the time factor (prospectively or retrospectively). Seen from a methodological point of view, studies such as those in table 1 should serve as models for our research in the next century. In this connection it is noteworthy that 2 of the most elegant, well performed, and conclusive studies took place very early in this period - the studies by Morris et al on physical inactivity from the 1950 s and 1960 s and the carbon disulfide study by Hernberg, Nurminen, Tolonen and their co-workers from the $1970 \mathrm{~s}$ and $1980 \mathrm{~s}$.

While the studies shown in table 1 constitute some of the highlights of the research on work and heart diseases from a methodological point of view, we have to turn to the psychosocial field to identify the theoretical highlights - the theories of the demand-control (or "job strain") model $(47,48)$ and of the effort-reward imbalance model (49). These 2 models have dominated the research on psychosocial factors and CVD since 1980. Until recently the effort-reward model was almost exclusively used by the Siegrist group in Germany, but researchers from London and Stockholm have now tested the model on data from the United Kingdom and Sweden, respectively $(43,50)$. The 2 models are sometimes considered "competitors" in the psychosocial field, but this is a fundamental mistake. They are not competing models about the same phenomenon, but models about different, and very important, phenomena in the psychosocial work environment. The job-strain model has decision latitude and skill discretion as 2 central components. This is a model about influence at work and about personal development, about democracy and growth. The effort-reward model, on the other hand, has distributive justice as its central component. Furthermore, this model deals with the long-term work career of people, and it incorporates the person's way of coping. The central dimension in this model is justice. While we are waiting for a fully elaborated paper with a theoretical and methodological comparison of these 2 models, I feel safe in concluding that the 2 models could very well both be confirmed by future research.

The literature on CVD and job strain was reviewed by Schnall et al in 1994 (13) and Kristensen in 1996 (17). These reviews, however, did not discuss a major new trend in the empirical literature. Since 1989, most of the studies on job strain and CVD have not been able to confirm the full model $(41,43,51-57)$. The dominating pattern of these studies has been that low control was associated with an increased risk of CVD (as predicted), while high demands was associated with a decreased risk of CVD (opposite the expected). As a result, the combination of low control and high demands was not associated with increased risk of CVD in these recent studies. Future reviews will have to scrutinize this new pattern very closely to identify possible explanations. In the next section I shall limit myself to discussing 2 closely connected methodological features of this research: the use of representative samples and the use of self-reported psychosocial exposures. 
Table 1. Highlights from 50 years of research on work and cardiovascular diseases.

\begin{tabular}{|c|c|}
\hline Study & Main results \\
\hline $\begin{array}{l}\text { Morris et al, } 1953(20) \\
\text { Morris et al, } 1965(21) \\
\text { Morris et al, } 1966(22)\end{array}$ & $\begin{array}{l}\text { Morris and his colleagues compared the incidence of ischemic heart disease among bus drivers and conductors of London } \\
\text { double-decker buses and found a higher risk among the drivers. It was concluded that the increased risk was due to lack of } \\
\text { physical activity among the bus drivers. }\end{array}$ \\
\hline Friedman et al, 1958 (23) & $\begin{array}{l}\text { The possible effects of urgent deadlines were studied in a cohort of } 40 \text { tax accountants followed for } 6 \text { months. Elevated } \\
\text { levels of serum cholesterol and shorter blood clotting time was observed during periods of high job stress due to } \\
\text { deadlines. }\end{array}$ \\
\hline $\begin{array}{l}\text { Hernberg et al, } 1976(24) \\
\text { Nurminen \& Hernberg, } \\
1985(25)\end{array}$ & $\begin{array}{l}343 \text { workers exposed to carbon disulfide and } 343 \text { control persons were followed for } 15 \text { years. A large excess risk of } \\
\text { ischemic heart disease among the exposed was eliminated after a vigorous intervention. }\end{array}$ \\
\hline Knipschild et al, 1977 (26) & $\begin{array}{l}\text { The use of different drugs among the inhabitants of } 2 \text { towns near the Schiphol airport was studied. One of the towns had } \\
\text { little air-craft noise exposure, while the other experienced increased noise exposure during a period of } 4 \text { years. The use of } \\
\text { cardiovascular drugs increased sharply in the exposed town, while the level was constant in the unexposed town. }\end{array}$ \\
\hline Zorn et al, 1 & $\begin{array}{l}\text { The mortality of sea pilots operating in German rivers was compared with the mortality of m } \\
\text { risk of ischemic heart disease deaths was } 3.5 \text { during the period } 1945-1960 \text { when the work } \\
\text { shortage of pilots. During the following } 13 \text { years the work load was normalized, and the relat }\end{array}$ \\
\hline $\begin{array}{l}\text { Kornitzer et al, } 1979(28) \\
\text { Kittel et al, } 1980(29)\end{array}$ & $\begin{array}{l}\text { Employees from a private bank and from a semiprivate sa } \\
\text { disease was about twice as high among the private bank }\end{array}$ \\
\hline Hogstedt, $1980(30)$ & $\begin{array}{l}\text { Earlier studies had found increased risk of "Monday morning death" among dynamite workers. In Hogstedt's studies (a } \\
\text { cohort study and a case-control study) an excess risk of cardiovascular disease was found among long-time employed } \\
\text { male dynamite workers. Ethylene glycol dinitrate was suggested as the causative agent. }\end{array}$ \\
\hline Orth-Gomér, & $\begin{array}{l}\text { The health effects of shift work were studied with a } \\
\text { system reduced risk of cardiovascular disease comp }\end{array}$ \\
\hline $\begin{array}{l}\text { Netterstrøm et al, } \\
1988(32)\end{array}$ & ig on less busy lines. The risk of \\
\hline Perry et al, 1988 (33) & $\begin{array}{l}\text { Occupants of multistory apartment buildings } \\
\text { location of supply cables. A higher risk of iscl }\end{array}$ \\
\hline Iversen et al, 1989 (34) & $\begin{array}{l}\text { ollowed before, during, and after the closure. A } \\
\text { d. }\end{array}$ \\
\hline Erikssen $e$ & $\begin{array}{l}\text { studied for } 7 \text { years. The average blood pressure and } \\
\text { a possible closure of the plant. }\end{array}$ \\
\hline $\begin{array}{l}\text { Gomel et al, } 1993(36) \\
\text { Odenburg et al, } 1995 \text { (37) }\end{array}$ & $\begin{array}{l}\text { Ambulance drivers from } 28 \text { stations were randomized to different ty } \\
\text { Behavioral counseling had the clearest effect on the risk of cardiovas }\end{array}$ \\
\hline $\begin{array}{l}\text { Flesch-Janys et al, } \\
1995(38)\end{array}$ & $\begin{array}{l}\text { The health effects of exposure to dioxins were studied in a historical cohort study. Exposed workers were compared with an } \\
\text { unexposed control group. A clear exposure-response trend of increasing risk for cardiovascular disease or ischemic heart } \\
\text { disease with increasing exposure levels was observed. }\end{array}$ \\
\hline Kawachi et al, 1997 (39) & $\begin{array}{l}\text { The association between passive smoking and ischemic heart disease was studied in a prospective cohort study of } 32046 \\
\text { never-smoking nurses followed for } 10 \text { years in the United States. The relative risk of ischemic heart disease was almost } \\
\text { doubled among the nurses regularly exposed to passive smoking at home or at work. }\end{array}$ \\
\hline Ising et al, $1997(40)$ & $\begin{array}{l}\text { The association between subjective noise exposure and the risk of ischemic heart disease was studied in a population- } \\
\text { based case-control study with } 395 \text { cases and } 2148 \text { controls. The relative risk of ischemic heart disease among the noise- } \\
\text { exposed subjects was more than doubled. }\end{array}$ \\
\hline $\begin{array}{l}\text { Bosna et al, } 1997(41) \text {; } \\
\text { Marmot et al, } 1997(42) \text {; } \\
\text { Bosma et al, } 1998(43)\end{array}$ & $\begin{array}{l}\text { The association between social class, psychosocial work environment and ischemic heart disease was investigated in a } \\
\text { prospective cohort study of } 10308 \text { civil servants. Low control and effort-reward imbalance explained a considerable } \\
\text { proportion of the social gradient. }\end{array}$ \\
\hline $\begin{array}{l}\text { Johansson et al, } 1998(44) \\
\text { Rydstedt et al,1998(45); } \\
\text { Evans et al, } 1999(46)\end{array}$ & $\begin{array}{l}\text { The number of job hassles of Stockholm bus drivers was reduced in a controlled intervention trial. The study showed that } \\
\text { separate bus lanes and a number of other improvements reduced job hassles and that the change resulted in lower blood } \\
\text { pressure and perceived stress in the intervention group. }\end{array}$ \\
\hline
\end{tabular}

\section{Cardiovascular and occupational epidemiology}

During the 20th century, the research fields of cardiovascular and occupational epidemiology have developed as 2 distinct disciplines with very little overlap and with minimal mutual awareness. Many reviews of cardiovascular risk factors have ignored the occupational exposures listed in the introduction, and many textbooks on occupational medicine have ignored cardiovascular diseases. The present situation is outlined in figure 1 . The situation could also be described in a slightly different way: occupational epidemiology focuses on environmental risk factors, while cardiovascular epidemiology has focused almost exclusively on individual risk factors.
The tradition of individual risk factors in cardiovascular epidemiology goes all the way back to the Framingham studies that were initiated immediately after the Second World War. The principle of sampling was representativeness, and the unit of sampling was the individual person. Consequently, the unit of analysis also became the individual person, and all the risk factors became individual. This research tradition agreed well with the prevailing American individualistic and liberalistic tradition, but the price was that little attention was paid to the social, economic, and occupational factors "behind" the individual risk factors. This tradition has often been criticized for being "victim blaming" and for ignoring class differences and living conditions. 
Most of the studies on job strain and CVD (and on effort-reward imbalance and CVD) have been performed as "Framingham-type studies" using representative samples from very heterogeneous populations. This approach has had the following unfortunate consequences: (i) since the populations were large and heterogeneous, most of the persons in the samples had "average" exposure on many of the psychosocial variables, but in analytical epidemiology it is important to have good exposure contrast; (ii) the information on the psychosocial exposures came from self-reports, and therefore it was impossible to distinguish the objective job condition from the appraisal and perception of the person; (iii) if the exposure was rare in the population, only a few with a given exposure were included in the study, and therefore the statistical power became too small; (iv) persons with identical psychosocial work conditions were classified into different exposure categories due to differences in the subjective appraisal of exposures, and this is the opposite of the "ecological fallacy" — the "individualistic fallacy" (the ecological fallacy consists of classifying persons with different exposures into the same category, whereas the individualistic fallacy consists of classifying persons with the same exposure into different categories); and (v) the studies became difficult to apply in actual prevention because the relevant risk factors, such as job demands, were measured with very abstract questionnaire methods.

The solution to these problems is simple. Studies on occupational factors and CVD should not use the individualistic methods of conventional cardiovascular epidemiology but instead learn from occupational epidemiology. The sampling should be performed insuch a way that exposures, not individuals, are the basis of the composition of the study base.

It is a surprising fact that the job-strain hypothesis has been tested in a large number of empirical studies but that no study has ever been designed to test this hypothesis in an optimal way. Most studies have been of the Framingham-type, in which job demands and control have simply been added to the list of individual risk factors. An optimal design of a job strain-CVD study would take into consideration the following: (i) a number of carefully chosen homogeneous job groups $(4-8$ would probably be sufficient) should be selected for the study, and these groups should have very different "exposures" (job demands, skill discretion, and decision authority); (ii) each of these homogeneous groups should have sufficient size to enable the researcher to study the effect of perceived versus objective exposures; (iii) the work conditions of each of the job groups in the study base should be measured using different methods (observations, questionnaires, expert ratings, already existing data, etc); (iv) the groups should be followed for a sufficient number of years in order to study the incidence of CVD and other end points; (v) the individual risk factors should be measured at the beginning for all subjects in order to study confounding and possible mechanisms; (vi) if feasible, intervention ("natural" or planned in connection with the study) could be part of the design.

\section{Future challenges}

In the preceding paragraphs I have gone into great detail with regard to the methodological features of studies on work and CVD. The main point is that we need to perform more studies that are based on explicit theory at the same time as being methodologically focused. When analytical (etiologic) studies are performed, representative samples of the population should usually be avoided. These recommendations are of particular relevance for research on psychosocial factors such as job strain, effort-reward imbalance, social support, job insecurity, and (risk of) unemployment. This is, however, far from the only challenge ahead of us in this field of research. I would like to comment briefly on the following 5 other vital points: (i) the use of intermediate end points, (ii) the perspectives of intervention research, (iii) new hypotheses in the field of chemical and physical exposures, (iv) a unifying model of heart diseases and environment, and ( $v$ ) integrated prevention of CVD.

\section{Intermediate end points}

In studies with small group sizes or with short follow-up periods, the number of hard CVD end points is usually

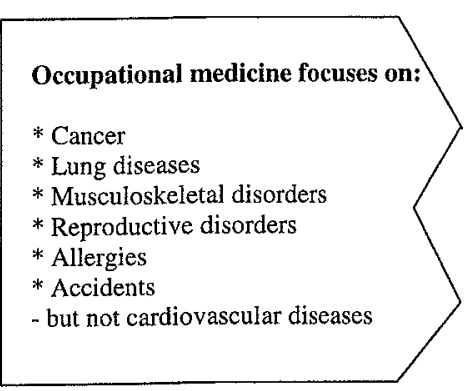

Figure 1. Missing connection between cardiovascular and occupational medicine. 
much too small to achieve sufficient statistical power. In such cases, the physiological precursors or risk factors of CVD will serve very well as intermediate end points. This method was used by Friedman et al (23), Orth-Gomér (31), Erikssen et al (35), and Gomel et al (36) in the studies mentioned in table 1 . When studying CVD, we are fortunate to have rather detailed knowledge about the pathological processes leading to CVD. Therefore we can use indicators of at least 4 different processes: high blood pressure, the atherosclerotic process, heart rate variations, and the process of thrombus formation.

The use of carotid artery wall thickness as a measure of the process of artherosclerosis is of particular interest. This method has been used in some studies and has yielded very interesting results $(58-60)$. The method is fascinating because it is noninvasive and still opens a window to the central process of atherosclerosis itself. In follow-up studies, the progression of atherosclerosis can be measured with good reliability with only a few years between the measurements $(61,62)$. Then every participant in the study gets a "hard end point": the difference between the 2 measures of carotid artery wall thickness.

\section{Intervention research}

Only 2 of the studies mentioned in table 1 were planned as intervention studies from the very beginning, the studies of Orth-Gomér (31) and Gomel and his co-workers $(36,37)$. The Finnish carbon disulfide study turned into an intervention study after a strong excess risk of ischemic heart disease was revealed by the researchers $(24,25)$. The studies of Iversen et al (34) and Knipschild \& Oudshoorn (26) were regarded and analyzed as natural experiments by the researchers. The other studies were analyzed and perhaps also perceived by the researchers as normal observational studies. It should be noted, however, that the distinction between an observational study and a natural experiment is not clear. The study by Erikssen et al (35) illustrates this point very well. The researchers studied the blood pressure and pulse of the workers over a number of years because they wanted to test the hypothesis that workers exposed to heat had higher blood pressure. After some years, the researchers observed a marked increase in average systolic blood pressure (15 $\mathrm{mm} \mathrm{Hg} ; 2 \mathrm{kPa}$ ), diastolic blood pressure (10 $\mathrm{mm} \mathrm{Hg} ; 1.3$ $\mathrm{kPa}$ ), and pulse ( 7 beats $/ \mathrm{min}$ ). In retrospect, the researchers found only 1 reasonable explanation: the factory had experienced serious financial difficulties, and there had been many rumors about a closure. Thus the workers had experienced a stressful period of very low predictability and control. The studies by Zorn et al (27) and Kornitzer $\&$ Kittel $(28,29)$ fall into the same category, since the explanation for the remarkable research results ("work stress") was put forward by the researchers as an ex post facto explanation.
The possibilities for performing well-planned (randomized) intervention studies at the worksites are limited. The work sites exist for producing services, goods, and profits, not as laboratories for researchers. Therefore we should be alert and open for "windows of opportunities" for quasi-experimental studies of many different kinds. Among such opportunities could be the introduction of a new way of organizing work, downsizing a company, new quality management systems at a hospital, use of a new chemical substance, (rumors about) a factory closure, the start of a new factory, introduction of a new shiftwork schedule, and the like. Researchers who have good and stable relationships with unions, managers, and occupational health services will have a much higher probability of discovering these opportunities.

\section{Chemical and physical risk factors}

With the exception of the monoclonal theory suggested by Benditt \& Benditt (63), the field of CVD and chemical or physical factors has been dominated by studies on single substances without a coherent theory of etiology or pathology. This situation was brought to an end with the introduction of the Seaton-Sjögren hypothesis a few years ago $(64,65)$. According to this hypothesis, different types of dust in the air cause a low-grade alveolar inflammation, which again causes the release of mediators. These mediators increase the level of plasma fibrinogen, which is a well-established risk factor for ischemic heart disease. The Seaton-Sjögren hypothesis is an example of a coherent theory that explains a number of seemingly disparate findings and that can be tested in a number of different ways. We need more theories of this type in the years to come. For example, the often-found association between blood lead and blood pressure can be seen as a "fact without a theory" $(14,16,66-68)$.

\section{Unifying model for society, stress and health}

I stated earlier that there was not necessarily a contradiction between the demand-control model and the effort-reward imbalance model. As we look ahead and face a new millenium, it might be appropriate to go a step further and suggest a unifying model, which embraces these 2 models and a number of other hypotheses as well. This model is based on an existentialist approach and operates with 3 distinct levels: the fundamental (existential) situation of the individual, the basic dimensions of stressors, and the characteristics of a healthy society. The model is presented in figure 2 .

To the left in the model the fundamental situation of a person is described with a few key terms. These concepts are (i) death (we are all going to die, but we do not know when), (ii) isolation (we are basically alone, but can only survive together with others), (iii) meaningless- 
ness (there is no given meaning with life, we have to create it ourselves), (iv) freedom (we are free to choose, but limited by social conditions), (v) injustice (life is basically unjust, but we urge for justice), and (vi) survival (we have to survive and reproduce ourselves). The first 4 of these terms are suggested by Yalom in his work on existential psychotherapy (69).

In the middle of the model we find the 6 basic dimensions of stressors: degree of predictability, social support, meaning, influence, effort-reward imbalance, and demands. These dimensions have been identified by basic stress research on both humans and animals. It should be noted that the 6 dimensions include the 2 (or 3 ) dimensions of the demand-control-(support) model and also the basic dimension of the effort-reward imbalance model. In 2 ongoing projects at the National Institute of Occupational Health, Copenhagen, we have included the dimensions of basic predictability and meaning of work in our studies and found that these dimensions contribute significantly to the variance of a number of dependent variables such as stress, self-rated health, and absence from work. According to this model, the optimal psychosocial work environment can be characterized as follows: a high level of basic predictability, good social support, meaningful work, a high level of influence at work, a balance between efforts and rewards, and demands that fit well the resources of the person. In future research on psychosocial factors at work (and outside work), I would recommend the inclusion of the 6 basic dimensions of stressors in figure 2 as core elements.

To the right in the model the corresponding societal dimensions are outlined. Society sets the conditions and limits for the 2 preceding levels: stressors and basic conditions of individuals. It follows from the model that a healthy society can be characterized by low levels of basic hazards and risks (wars, crime, famine, pollution, etc), high social integration, a coherent intellectual and spiritual culture, a democratic system, a high degree of justice, and education and employment for citizens. The importance of these dimensions is dramatically demonstrated currently by the situation in the former Communist countries and also by the more chronic situation in Africa. According to the predictions of the World Health Organization, the main health problems of the future will be found in these 2 regions of the world (2).

The basic message of this model is that we cannot limit ourselves to only 1 level (be it individual, work, or society) and that we should include all 6 dimensions at the 3 levels in our total understanding of the processes and factors leading to poor (cardiovascular) health. Another central aspect of the model is that the individual should not be regarded only as a passively exposed object, but also as an actively choosing, thinking, feeling, and acting person (the existential level).

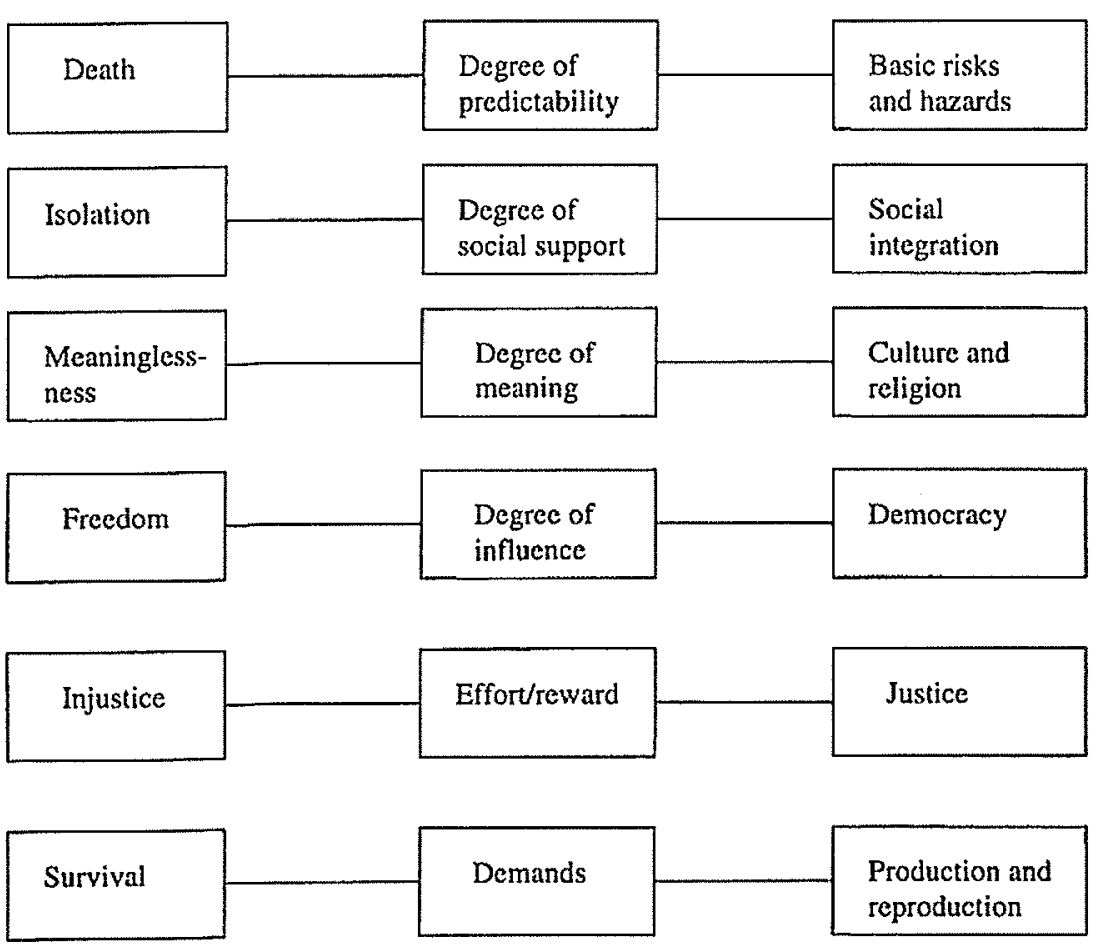

Figure 2. Unifying model for society, stress and health. 


\section{Integrated prevention}

The ultimate goal of occupational medicine and epidemiology is to provide the basis for evidence-based prevention. While our research has to be focused and specific, primary prevention should be nonspecific and integrated. Healthy people are not interested in avoiding just 1 specific disease, but in staying healthy as long as possible. It may be considered a problem that the possible occupational risk factors for CVD listed in the Introduction are not all generally accepted as causal risk factors. It should, however, be kept in mind that all these factors are also risk factors for other diseases. Therefore there are many good reasons to reduce or eliminate these factors.

Integrated prevention at the worksite should include the following 3 different prevention strategies: (i) environmental intervention (reduction of harmful exposures at work), (ii) worksite health promotion (focusing on individual life-style and resources), (iii) rehabilitation at the worksite (focusing on those employees who have (had) a disease). If these 3 strategies of prevention are combined, the positive effects of each of the strategies will tend to strengthen the others. Healthy people will contribute to the healthy workplace and the healthy workplace will help the people stay healthy and contribute to their development and growth. Research on CVD and work can play an important part in the development of integrated prevention in the next century.

\section{References}

1. Kaplan GA, Keil JE. Socioeconomic factors and cardiovascular disease: a review of the literature. Circulation 1993;88:1973-98.

2. Murray JL, Lopez AD, editors. The global burden of disease. Geneva: World Health Organization, 1996.

3. Kristensen TS, Kornitzer M, Alfredsson L. Social factors, work, stress and cardiovascular disease prevention in the European Union. Brussels: The European Heart Network, 1998.

4. House JS, Landis KR, Umberson D. Social relationships and health. Science 1988;241:540—5.

5. Theorell T. Critical life changes: a review of research. Psychother Psychosom 1992;57:108-17.

6. Rahe RH. Recent life changes and coronary heart disease: 10 years' research. In: Fisher S, Reason J, editors. Handbook of life stress, cognition and health. London: John Wiley \& Sons, 1988:317-33.

7. Jin RL, Shah CP, Svoboda TJ. The impact of unemployment on health: a review of the evidence. Can Med Assoc J 1995; 153:529-40.

8. Steenland K. Epidemiology of occupation and coronary heart disease: research agenda. Am J Ind Med 1996;30:495-9.

9. Rosenman KD. Cardiovascular disease and work place exposures. Arch Environ Health 1984;39:218-24.

10. Monson RR. Occupational and cardiovascular disease. In: Monson RR. Occupational epidemiology, Boca Raton (FL):
CRC Press Inc, 1980:202-7.

11. Fine LJ. Occupational heart disease. In: Rom WN, editor. Environmental and occupational medicine. Boston (MA): Little, Brown and Co, 1983:359-65.

12. Pickering TG. Does psychological stress contribute to the development of hypertension and coronary heart disease? Eur J Cin Pharmacol 1990;39:suppl 1:S1-7.

13. Schnall PL, Landsbergis PA, Baker D. Job strain and cardiovascular disease. Ann Rev Public Health 1994;15:381-411.

14. Kristensen TS. Cardiovascular diseases and the work environment: a critical review of the epidemiologic literature on chemical factors [review]. Scand J Work Environ Health $1989 ; 15: 245-64$.

15. Kristensen TS. Cardiovascular diseases and the work environment: a critical review of the epidemiologic literature on nonchemical factors [review]. Scand J Work Environ Health 1989;15:165-79.

16. Kristensen TS. Cardiovascular diseases and the work environment. In: Cheremisinoff PN, editor. Encyclopedia of environmental control technology; vol 7 (High-hazard pollutants). Houston (TX): Gulf Publishing Company, 1994:217-43.

17. Kristensen TS. Job stress and cardiovascular disease: a theoretic critical review. J Occup Health Psychol 1996;3:246-60.

18. Karasek R, Theorell T. Healthy work. New York (NY): Basic Books, 1990.

19. Olsen O, Kristensen TS. Impact of work environment on cardiovascular diseases in Denmark. J Epidemiol Community Health 1991;45:4-10.

20. Morris JN, Heady JA, Raffle PAB, Roberts CG, Parks JW. Coronary heart-disease and physical activity of work, I: coronary heart-disease in different occupations. Lancet 1953:2:1053-7.

21. Morris JN, Heady JA, Raffle PAB, Roberts CG, Parks JW. Coronary heart-disease and physical activity of work, II: statement and testing of provisional hypothesis. Lancet $1953 ; 2: 1111-20$.

22. Morris JN, Kagan A, Pattison DC, Gardner MJ, Raffle PAB Incidence and prediction of ischaemic heart-disease in London busmen. Lancet 1966;2:553-9

23. Friedman M, Rosenman RH, Caroll V. Changes in the serum cholesterol and blood clotting time in men subjected to cyclic variation of occupational stress. Circulation 1958;17:85261.

24. Hernberg S, Tolonen M, Nurminen M. Eight-year follow-up of viscose rayon workers exposed to carbon disulfide. Scand J Work Environ Health 1976;2:27-30.

25. Nurminen M, Hernberg S. Effects of intervention on the cardiovascular mortality of workers exposed to carbon disulphide: a 15 year follow-up. Br J Ind Med 1985;42:32-5.

26. Knipschild P, Oudshoorn N. Medical effects of aircraft noise: drug survey. Int Arch Occup Environ Health 1977;40:197200.

27. Zorn EW, Harrington JM, Goethe H. Ischemic heart disease and work stress in West German sea pilots. $\mathbf{J}$ Occup Med 1977;19:762-5.

28. Kornitzer MD, Dramaix M, Gheyssens H. Incidence of ischemic heart disease in two Belgian cohorts followed during 10 yr. Eur J Cardiol 1979;9:455-72.

29. Kittel F, Kornitzer M, Dramaix M. Coronary heart disease and job stress in two cohorts of bank clerks. Psychother Psychosom 1980;34:110-23.

30. Hogstedt C. Dynamite: occupational exposure and health effects [thesis]. Linköping: Department of Occupational Medicine, 1980. 
31. Orth-Gomér K. Intervention on coronary risk factors by adapting a shift work schedule to biologic rhythmicity. Psychosom Med 1983;45:407-15.

32. Netterstrøm B, Juel K. Impact of work-related and psychosocial factors on the development of ischemic heart disease among urban bus drivers in Denmark. Scand J Work Environ Health 1988;14:231-8.

33. Perry $\mathrm{S}$, Pearl L. Power frequency magnetic field and illness in multi-storey blocks. Public Health 1988;102:11-8.

34. Iversen L, Sabroe S, Damsgaard MT. Hospital admissions before and after shipyard closure. BMJ 1989;299:1073-7.

35. Erikssen J, Knudsen K, Mowinckel P, Guthe T, Holm JPL, Brandtzæg $\mathrm{R}$, et al. Blodtryksstigning hos stresseksponerte industriarbeidere [Increase in blood pressure among stress exposed industrial workers]. Tidsskr Nor Laegeforen 1990;110:2873-7.

36. Gomel M, Oldenburg B, Simpson JM, Owen N. Work-site cardiovascular risk reduction: a randomized trial of health assessment, education, counseling, and incentives. Am J Public Health 1993;83:1231-8.

37. Oldenburg B, Owen N, Parle M, Gomel M. An economic evaluation of four work site based cardiovascular risk factor interventions. Health Educ Q 1995;22:9-19.

38. Flesch-Janys D, Berger J, Gurn P, Manz A, Nagel S, Waltsgott $\mathrm{H}$, et al. Exposure to polychlorinated dioxins and furans (PCDD/F) and mortality in a cohort of workers from a herbicide-producing plant in Hamburg, Federal Republic of Germany. Am J Epidemiol 1995;142:1165-75.

39. Kawachi I, Colditz GA, Speizer FE, Manson JA, Stampfer MJ, Willett WC, et al. A prospective study of passive smoking and coronary heart disease. Circulation 1997;95:2374-9.

40. Ising H, Babisch W, Kruppa B, Lindthammer A, Wiens D. Subjective work noise: a major risk factor in myocardial infarction. Soz Präventivmed 1997;42:216-22.

41. Bosma H, Marmot MG, Hemingway H, Nicholson AC, Brunner E, Stansfeld SA. Low control and risk of coronary heart disease in Whitehall II (prospective cohort) study. BMJ 1997;314:558-65.

42. Marmot MG, Bosma H, Hemingway H, Brunner E, Stansfeld $S$. Contribution of job control and other risk factors to social variations in coronary heart disease incidence. Lancet 1997;350:235-9.

43. Bosma H, Peter R, Siegrist J, Marmot M. Two alternative job stress models and the risk of coronary heart disease. Am $\mathrm{J}$ Public Health 1998;88:68-74.

44. Johansson G, Evans GW, Rydstedt LW, Carrere S. Job hassles and cardiovascular reaction patterns among urban bus drivers. Int J Behav Med 1998;5:267-80.

45. Rydstedt LW, Johansson G, Evans GW. The human side of the road: improving the work conditions of urban bus drivers. J Occup Health Psychol 1998:3:161-71.

46. Evans GW, Johansson G, Rydstedt L. Hassles on the job: a study of a job intervention with urban bus drivers. J Organ Behav 1999;20:199-208.

47. Karasek RA, Theorell T. Healthy work. New York (NY): Basic Books, 1990.

48. Theorell T, Karasek RA. Current issues relating to psychosocial job strain and cardiovascular disease research. J Occup Health Psychol 1996;1:9-26.

49. Siegrist JA. Adverse health effects of high-effort/low-reward conditions. J Occup Health Psychol 1996;1:27-41.

50. Peter R, Alfredsson L, Hammar N, Siegrist J, Theorell T, Westerholm P. High effort, low reward, and cardiovascular risk factors in employed Swedish men and women: baseline results from the WOLF Study. J Epidemiol Community Health 1998;52:540-7.

51. Reed DM, LaCroix AZ, Karasek RA, Miller DW, MacLean CA. Occupational strain and the incidence of coronary heart disease. Am J Epidemiol 1989;129:495-502.

52. Hall EM, Johnson JV, Tsou T-S. Women, occupation, and risk of cardiovascular morbidity and mortality. Philadelphia (PA): Hanley \& Belfus Inc, 1993:709-19. Occupational medicine: state of the art reviews, no 8.

53. Alterman T, Shekelle RB, Vernon SW, Bureau KD. Decision latitude, psychological demands, job strain, and coronary heart disease in the Western Electric Study. Am J Epidemiol 1994;139:620-7.

54. Johnson JV, Stewart W, Hall EM, Fredlund P, Theorell T. Long-term psychosocial work environment and cardiovascular mortality among Swedish men. Am J Public Health 1996;86:324-31.

55. Steenland K, Johnson J, Nowlin S. A follow-up study of job strain and heart disease among males in the NHANES1 population. Am J Ind Med 1997;31:256-60.

56. Hammar N, Alfredsson L, Johnson JV. Job strain, social support at work, and incidence of myocardial infarction. Occup Environ Med 1998;55:548-53.

57. Theorell T, Tsutsumi A, Hallquist J, Reuterwall C, Hogstedt $C$, Fredlund P, et al. Decision latitude, job strain, and myocardial infarction: a study of working men in Stockholm. Am J Public Health 1998;88:382-8.

58. Heiss G, Sharrett AR, Barnes R, Chambless LE, Szklo M, Alzola C. Carotid atherosclerosis measured by B-mode ultrasound in populations: associations with cardiovascular risk factors in the ARIC Study. Am J Epidemiol 1991;134:2506.

59. Salonen JT, Salonen R. Ultrasonographically assessed carotid morphology and the risk of coronary heart disease. Arterioscler Thromb 1991;11:1245-9.

60. Muntaner C, Nieto FJ, Cooper L, Meyer J, Szklo M, Tyroler HA. Work organization and atherosclerosis: findings from the ARIC study. Am J Prev Med 1998;14:9—18.

61. Lynch J, Krause N, Kaplan GA, Salonen R, Salonen JT. Workplace demands, economic reward, and progression of carotid atherosclerosis. Circulation 1997;96:302-7.

62. Everson SA, Lynch JW, Chesney MA, Kaplan GA, Goldberg $\mathrm{DE}$, Shade $\mathrm{SB}$, et al. Interaction of workplace demands and cardiovascular reactivity in progression of carotid atherosclerosis: population based study. BMJ 1997;314:553-8.

63. Benditt EP, Benditt JM. Evidence for a monoclonal origin of human atherosclerotic plaques. Proc Natl Acad Sci USA 1973;70:1753-6.

64. Seaton A, MacNee W, Donaldson K, Godden D. Particulate air pollution and acute health effects. Lancet 1995;345:1768.

65. Sjögren B. Occupational exposure to dust: inflammation and ischaemic heart disease. Occup Environ Med 1997;54:4669.

66. Møller L, Kristensen TS. Blood lead as a cardiovascular risk factor. Am J Epidemiol 1992;136:1091-100.

67. Sharp DS, Becker CE, Smith AH. Chronic low-level lead exposure: its role in the pathogenesis of hypertension. Med Toxicol 1987;2:210-32.

68. Staessen JA, Bulpitt CJ, Fagard R, Lauwerys RR, Roels H, Thijs L, et al. Hypertension caused by low-level lead exposure: myth or fact? J Cardiovasc Risk 1994;1:87—97.

69. Yalom ID. Existential psychotherapy. New York (NY): Basic Books, 1980 